\title{
ADAPTATION OF THE DEO-MOHAN ACHIEVEMENT MOTIVATION (N-ACH) SCALE FOR URBAN STUDENTS IN BANGLADESH
}

\author{
Samira Mahjabin ${ }^{1}$ \\ Most. Aeysha Sultana ${ }^{2}$
}

\begin{abstract}
Achievement motivation is a major secondary drive that makes a person strive towards challenging goals and achieving success. So, it is necessary to learn the measures of achievement motivation of the adolescents and take steps accordingly in the educational setting for their betterment. There is a lack of measuring tools of achievement motivation in Bangladesh. Considering the significance of the tool, the current study aimed to adapt the Deo-Mohan Achievement Motivation (n-Ach) scale in the Bangladeshi cultural perspective. The scale was adapted following the ITC guidelines and was administered on 228 adolescents aged from 13 to 19 years. The sample was chosen using the purposive and convenient sampling techniques. Collected data indicated satisfactory reliability (Cronbach's alpha, test-retest reliability coefficient). Item analysis was done by calculating the item-total correlation. Content validity was checked by experts and correlation with Rosenberg self-esteem scale was measured to see the concurrent validity. Exploratory factor analysis was done to see the construct validity. Factor analysis results revealed that the 10 factors of the Bangla $n$-Ach scale together explained $58.33 \%$ of the total variance. Thus, the adapted version of Deo-Mohan Achievement Motivation (n-Ach) Scale is expected to be a reliable and valid scale to measure achievement motivation of Bangladeshi adolescents.
\end{abstract}

Keywords: achievement motivation, adolescent, adaptation, reliability, validity

Achievement motivation is considered as a vital issue in the psychological and educational research field. It refers to one's motivation to engage in activities to meet realistic goals and have a sense of accomplishment. The concept was developed and

1 Samira Mahjabin, BS Honours, Department of Psychology, University of Dhaka, Bangladesh. Email: samiramahjabin468@gmail.com

2 Most. Aeysha Sultana, PhD is Associate Professor, Department of Psychology, University of Dhaka, Bangladesh. Email: aeysha_sultana06@yahoo.com

Social Science Review [The Dhaka University Studies, Part-D], Vol. 37, No. 2, December 2020 
popularized by the American psychologist David McClelland. Achievement motivation refers to individual's characteristic of continuing strive to be successful in competition with others (McClelland, Atkinson, Clark, \& Lowell, 1953). Individual with high achievement motivation sets a particular standard of excellence and rigorously strives to consummate unique accomplishments (Atkinson, 1957). Achievement motivation is an important social need and learned tendency (Newcomb, 1964). It also directly influences academic performance (McClelland, 1961). Individuals with high achievement motivation perform better in academic activities (Kołodziej, 2010; Tella, 2007). The theory of needs explains the motivation and stresses the types of needs and the approaches to satisfy them. The theory stresses the three important factors given below (McClelland et al., 1953):

1. Need for Achievement (n-Ach): It is a learned characteristic in which an individual strives to achieve something difficult and obtains satisfaction by achieving challenging goals.

2. Need for Affiliation (n-Aff): It refers to the need of the individuals to establish interpersonal relationships. High n-Aff tendency is associated with a strong desire to be loved (Feldman, 2017).

3. Need for Power (n-Pow): The need for power is the tendency to have authority, control, and inducing others (Feldman, 2017).

The term Need for Achievement (n-Ach) was first used by Henry Murray (1938). The theory was formulated by McClelland and his associates. It is largely concerned with motivation. McClelland argued that the need for achievement, power and affiliation varies from person to person. Achievement motivation can lead to economic and professional success (McClelland, 1985). Research suggests that, from the measure of achievement motivation, predictions like student's academic performance, variables related to entrepreneurial behavior or a country's economic growth can be made. Achievement oriented individuals tend to master complex tasks and find solution in difficult situations. They usually set precise goals and show long term involvement in achieving those specific goals. Achievement motivation is positively related with self-esteem. Several studies conducted on high school students and under graduates in different countries (India, Ghana, Iran) show that self-esteem is positively correlated with achievement motivation (Ajayi, 2002; Aktop \& Erman, 2006; Coopersmith, 1967; Stericker \& Johnson 1977). Studies also show that selfesteem significantly predicts achievement motivation (Odame-Mensah, 2019). 
Researchers have shown interest to find out if the levels of achievement motivation vary across gender: male and female. Several previous studies showed contradictory results regarding the effect of gender difference on achievement motivation. Some studies showed significant variation in achievement motivation scores across gender (Shekhar \& Devi, 2012; Wani, 2015). On the other hand, some research revealed non-significant variation in achievement motivation scores between boys and girls (Kaushik \& Rani, 2005; Nagarathanamma \& Rao, 2007). Research on Bangladeshi students showed non-significant difference between male and female according to achievement motivation score (Anjuman, 2006).

\section{Rationale of the Study}

In educational setting, achievement motivation is considered as an important concept. It differs from person to person. It is also associated with important concepts like self-esteem, academic performance, self-concept etc. Measuring achievement motivation can help to determine high and low motivated students and necessary initiatives can be taken to help the low motivated students to improve their achievement motivation. There is a lack of tools to measure achievement motivation of Bangladeshi adolescents. Hence, the present study aimed to adapt the n-Ach scale to measure the achievement motivation of urban students (adolescents) in Bangladesh.

\section{Objective of the study}

The objective of the current study was to translate and adapt the Achievement Motivation Scale (n-Ach) in the context of Bangladeshi culture.

\section{Method}

\section{Participants}

As the original n-Ach scale was developed for adolescents, the Bangla version of this scale was administered on a total of 228 adolescents selected from Dhaka city, aged 13-19 years. Purposive and convenience sampling techniques were used to select 228 participants. Among them, 115 were female (50.44\%) and 113 $(49.56 \%)$ were male. 3 participants did not complete the questionnaire. Therefore, the final sample consisted of 225 participants.

The sample size used in the present study can be considered adequate based on the opinion of several experts and researchers. The minimum required sample 
size in factor analysis has been recommended from 100 (Gorsuch, 1983; Kline, 1979) to 250 (Cattell, 1978). The recommendation for participants to items/variables ratio varies from 2:1 (Guilford, 1956; Kline, 1979) to 10:1 (Marascuilo \& Levin, 1983; Nunnally, 1978). In the present study, the sample size may be considered as adequate and satisfactory because the number of participants was more than 4 times the number of n-Ach items or variables.

\section{Measures}

Data were collected with the following measures - Personal Information Form, Bangla version of the Deo-Mohon Achievement Motivation (n-Aach) Scale and Bangla version of the Rosenberg Self-esteem Scale.

Personal Information Form: This form was used for collecting information regarding the participants' name, gender, age, class, roll, height, weight, and name of their educational institution.

The Deo-Mohon Achievement Motivation (n-Ach) Scale: Pratibha Deo and Asha Mohan (1985) have developed the Deo-Mohan Achievement Motivation Scale (nAch). It is a self-rated, 50-item scale for measuring the need for achievement in adolescents. The original scale consists of 15 factors- 'academic motivation', 'need for achievement', 'academic challenge', 'achievement anxiety', 'importance of grades', 'meaningfulness of task', 'relevance of school/college to future goals', 'attitude towards education', 'work methods', attitude towards teachers', 'interpersonal relations', 'individual concern', 'general interest', 'dramatics' and 'sports'. Among the 50 items, 37 items are positive and 13 (item number 1, 12, 13, $14,17,18,19,20,21,22,32,34,37$ ) are negative. Each positive item has 5 responses to rate 4 for 'always', 3 for 'frequently', 2 for 'sometimes' 1 for 'rarely' and 0 for 'never'. The scoring was reverse for the negative items, i. e., 0 to 4 for the responses, 'always' to 'never' accordingly. Higher score indicates higher achievement motivation. The test-retest reliability of the original scale is .78 for girls, .67 for boys and .69 for mixed group. Cronbach's coefficient alpha was .86 for overall male and female. The item validity was .54 . The scale yields a correlation coefficient of .75 with the Aberdeen Academic Motivation Inventory of Entwistle (1968). The results support that the original scale of achievement motivation is sufficiently valid to measure achievement motivation of adolescents.

Bangla version of the Rosenberg Self-esteem Scale: The Bangla version of the Rosenberg's (1965) self-esteem scale was adapted by Ilyas (2003). It is a self- 
rated, 10-item scale developed for adolescents in which 5 items are positive $(1,3$, $4,7,10)$ and 5 items are negative. Each item has 4 responses: 'strongly agree', 'agree', 'disagree' and 'strongly disagree'. The scoring for positive item is 3 to 0 for the responses, 'strongly agree to strongly disagree' accordingly and the reverse scoring ( 0 to 3 ) for the negative items. The score ranges from 0 to 30 . Higher score indicates higher self-esteem. The significant correlation $(r=.760, p$ $<.005)$ between the scores of English and Bangla versions of the scale indicates satisfactory translation reliability. The Cronbach's alpha for the Bangla version of the scale was .87 which indicates the internal consistency of the scale.

\section{Adaptation Process}

The adaptation of the achievement motivation scale (n-ach) was a multistage process. The International Test Commission (ITC) Guidelines were followed. The adaptation process included the following steps.

1. Forward translation: The Achievement Motivation Scale was translated by the first author in Bangla and further modifications were made by the second author. Easy translation without altering the meaning was given priority.

2. Consulting with experts: The forward translation was judged by 5 faculty members of the Department of Psychology, University of Dhaka. Some words and items were changed according to their suggestion. Some translated items were further revised consulting with a professor of Psychology, University of Dhaka. A faculty member of the Department of Linguistics, University of Dhaka assessed the linguistic and semantic equivalence, structure of the sentences and the grammar.

3. Back translation: Two translators fluent in both Bangla and English, were chosen who translated the Bangla version of the Achievement Motivation scale to English. Their translations were compared with the original scale (English version) which indicated a good congruence between the Bangla and the English versions of the scale.

\section{Administration}

The Bangla version of the achievement motivation (n-Ach) scale was administered on 228 participants. At first, participants were asked if they were willingly participating in the research and an informed consent was taken from them. After that they were given verbal instructions about how to fill-up the questionnaire. They were asked to fill-up the personal information sheet first and then read the questions carefully and response accordingly. There was no time 
constraint for responding to the questionnaire. Participants were given assurance that their information would be used only for research purpose and maintained with confidentiality. They were also requested to respond honestly. They were asked to raise hands if they faced difficulty in understanding any item. After completing the questionnaire, they were thanked for their cooperation. Duration of answering the questionnaire lasted from 30 to 50 minutes.

\section{Results}

Item Analysis

The internal consistency of the Bangla version of the $\mathrm{n}$-Ach scale was calculated by determining the corrected item-total correlation (see Table1).

Table 1: Corrected Item-total Correlation of the n-Ach Scale

\begin{tabular}{|c|c|c|c|}
\hline Items & $\begin{array}{l}\text { Corrected Item- } \\
\text { total Correlation }\end{array}$ & Items & $\begin{array}{l}\text { Corrected item- } \\
\text { total Correlation }\end{array}$ \\
\hline Item 1 & .475 & Item 26 & .546 \\
\hline Item 2 & .487 & Item 27 & .557 \\
\hline Item 3 & .484 & Item 28 & .498 \\
\hline Item 4 & .507 & Item 29 & .580 \\
\hline Item 5 & .442 & Item 30 & .475 \\
\hline Item 6 & .477 & Item 31 & .353 \\
\hline Item 7 & .397 & Item 32 & .408 \\
\hline Item 8 & .422 & Item 33 & .594 \\
\hline Item 9 & .519 & Item $34 *$ & .152 \\
\hline Item 10 & .357 & Item 35 & .439 \\
\hline Item 11 & .410 & Item 36 & .343 \\
\hline Item 12 & .256 & Item $37 *$ & .197 \\
\hline Item $13^{*}$ & .112 & Item 38 & .410 \\
\hline Item 14 & .386 & Item 39 & .468 \\
\hline Item 15 & .413 & Item 40 & .340 \\
\hline Item 16 & .288 & Item 41 & .316 \\
\hline Item 17 & .434 & Item 42 & .231 \\
\hline Item 18 & .460 & Item $43^{*}$ & -.083 \\
\hline Item 19 & .384 & Item $44 *$ & .189 \\
\hline Item 20 & .429 & Item 45 & .217 \\
\hline Item 21 & .434 & Item 46 & .249 \\
\hline Item $22 *$ & -.226 & Item 47 & .345 \\
\hline Item $23^{*}$ & -.162 & Item 48 & .249 \\
\hline Item 24 & .387 & Item $49^{*}$ & .164 \\
\hline Item $25^{*}$ & -.077 & Item 50 & .291 \\
\hline
\end{tabular}

Note: *Dropped items in the Bangla version of the scale due to negative item-total correlation 
From the values of the item-total correlation, 9 items (Items- 13, 22, 23, 25, 34, $37,43,44,49)$ were detected to have negative or low $(r<.2)$ correlation score. Hence, these items were dropped. Rest of the 41 items were found to have corrected item-total correlation above .2 showing good internal consistency.

\section{Reliability of the Scale}

The reliability coefficients of the Bangla version of the n-Ach scale were determined by Cronbach's alpha and test-retest methods.

Cronbach's Alpha: The Cronbach's alpha was found .902 for the 41 items of the Bangla version of the n-Ach scale which is satisfactory (shown in Table 2).

Table 2: Cronbach's Alpha of the Bangla n-Ach Scale

\begin{tabular}{ccc}
\hline Cronbach's Alpha & $\begin{array}{c}\text { Cronbach's Alpha Based on } \\
\text { Standardized Items }\end{array}$ & N of Items \\
\hline .902 & .907 & 41 \\
\hline
\end{tabular}

Test- retest Reliability: Among the 225 participants the scale was re-administered on 26 (boys $=12$ and girls $=14$ ) participants in 3 weeks interval. The test- retest reliability coefficient was .905 which is very high and satisfactory.

\section{Validity of the Scale}

The validity of the Bangla version of the n-Ach was determined by the following methods:

Content validity: The Bangla version of the n-Ach scale was evaluated by an expert panel of 9 faculty members of the Department of Psychology, University of Dhaka, Bangladesh. The evaluation and remarks of the expert panel assured the content validity of the scale.

Factorial Validity: Construct validity of the scale was determined through exploratory factor analysis.

To justify the suitability of factor analysis, the KMO measure of sampling adequacy was calculated (Table 3). The KMO measure indicated a value of .850 which is much greater than the recommended value of .60 (Kaiser, 1970). The Bartlett's test of sphericity indicated a chi-square $\left(\chi^{2}\right)$ value of 3268.108 ( $p<$ $.001)$. All these values together support that correlation matrix is not an identity matrix and is significant for factor analysis. 
Table 3: Values of the KMO and Bartlett's Test

\begin{tabular}{|c|c|c|}
\hline \multicolumn{2}{|c|}{ Kaiser-Meyer-Olkin measure of sampling adequacy. } & .850 \\
\hline \multirow{3}{*}{ Bartlett's Test of Sphericity } & Approx. Chi-Square & 3268.108 \\
\hline & df & 820 \\
\hline & Sig. & .000 \\
\hline
\end{tabular}

\begin{tabular}{|c|c|c|c|c|c|c|c|c|c|c|}
\hline \multirow{2}{*}{ Items } & \multicolumn{10}{|c|}{ Component } \\
\hline & 1 & 2 & 3 & 4 & 5 & 6 & 7 & 8 & 9 & 10 \\
\hline Item 18 & .776 & & & & & & & & & \\
\hline Item 20 & .766 & & & & & & & & & \\
\hline Item 19 & .722 & & & & & & & & & \\
\hline Item 21 & .701 & & & & & & & & & \\
\hline Item 1 & .633 & & & & & & & & & \\
\hline Item 32 & .609 & & .362 & & & & & & & \\
\hline Item 14 & .554 & & .345 & & & & & & & \\
\hline Item 29 & .543 & .353 & .349 & & & & & & & \\
\hline Item 17 & .487 & & & & & & & & .319 & \\
\hline Item 28 & .450 & & .426 & & & & & & & \\
\hline Item 3 & .392 & & & & & & & & & \\
\hline Item 8 & & .698 & & & & & & & & \\
\hline Item 10 & & .611 & & & & & & & & \\
\hline Item 5 & & .607 & & & & & & & & \\
\hline Item 30 & & .582 & & & & & & & & \\
\hline Item 7 & & .563 & & & .320 & & & & & \\
\hline Item 39 & & .541 & & & .319 & & & & & \\
\hline Item 4 & & .515 & & & & & & & & \\
\hline Item 26 & .327 & & .654 & & & & & & & \\
\hline Item 9 & & & .594 & & & & & & & \\
\hline Item 2 & .330 & & .522 & & & & & & & \\
\hline Item 27 & .312 & & .507 & & .359 & & & & & \\
\hline Item 47 & & & & .744 & & & & & & \\
\hline Item 46 & & & & .726 & & & & & & \\
\hline
\end{tabular}




\begin{tabular}{|c|c|c|c|c|c|c|c|c|c|c|}
\hline \multirow{2}{*}{ Items } & \multicolumn{10}{|c|}{ Component } \\
\hline & 1 & 2 & 3 & 4 & 5 & 6 & 7 & 8 & 9 & 10 \\
\hline Item 50 & & & .311 & .660 & & & & & & \\
\hline Item 42 & & & & .538 & & & & & & \\
\hline Item 11 & & & & & .719 & & & & & \\
\hline Item 48 & & & & & .488 & & & & & \\
\hline Item 24 & & & & & & .717 & & & & \\
\hline Item 38 & & & & & & .612 & .346 & & & \\
\hline Item 35 & & & & & .364 & .407 & & & & \\
\hline Item 41 & & & & & & & .585 & & & \\
\hline Item 31 & & & & & & .354 & .556 & & & \\
\hline Item 6 & & & .301 & & .392 & & .461 & & & \\
\hline Item 33 & & & & & & & .350 & & & \\
\hline Item 45 & & & & & & & & .813 & & \\
\hline Item 40 & & & & & .357 & & & .438 & & \\
\hline Item 12 & & & & & & & & & .726 & \\
\hline Item 36 & & & & & & & & & .590 & \\
\hline Item 16 & & & & & & & & & & .770 \\
\hline Item 15 & & & & & .357 & & & & & .492 \\
\hline
\end{tabular}

Factor loadings $<.03$ were suppressed.

Extraction Method: Principal Component Analysis.

Rotation Method: Varimax with Kaiser normalization.

Rotation converged in 12 iterations.

Table 4 shows that the 41 items of the Bangla version of the n-Ach scale falls in 10 factors. These 10 factors together accounted for $58.33 \%$ of the total variance (data not shown). Some factors did not conceptually fit with the corresponding factors of the original scale. Hence, new names were given to the factors according to their nature following the concepts of Achievement motivation theory. Before labelling, items that cross loaded between different factors were identified. The cross loaded items were grouped in the factors that had greater loading and best conceptual fit. N-Ach Item 6 cross-loaded in factor 3, 5 and 7 . Although it had greater factor loading in factor 7, it was grouped in factor 3 for its best conceptual fit. The factors identified in the Bangla n-Ach scale were'academic motivation' (items-1, 3, 14, 17, 18, 19, 20, 21, 28, 29, 32), 'need for 
achievement' (items- 4, 5, 7, 8, 10, 30, 39), 'work methods'(items- 2, 6, 9, 26, 27), 'interest in sports' (items- 42, 46, 47, 50), 'attitude towards competition' (items- 11,48), 'success seeking' (items- 24, 35, 38), 'attitude towards scholar personalities'(items- 31, 33, 41), ' interest in extracurricular activities' (items$40,45)$, ' need to excel' (items- 12, 36), 'relevance of tasks' (items- 15, 16).

A scree plot of the components is shown in Figure 1.

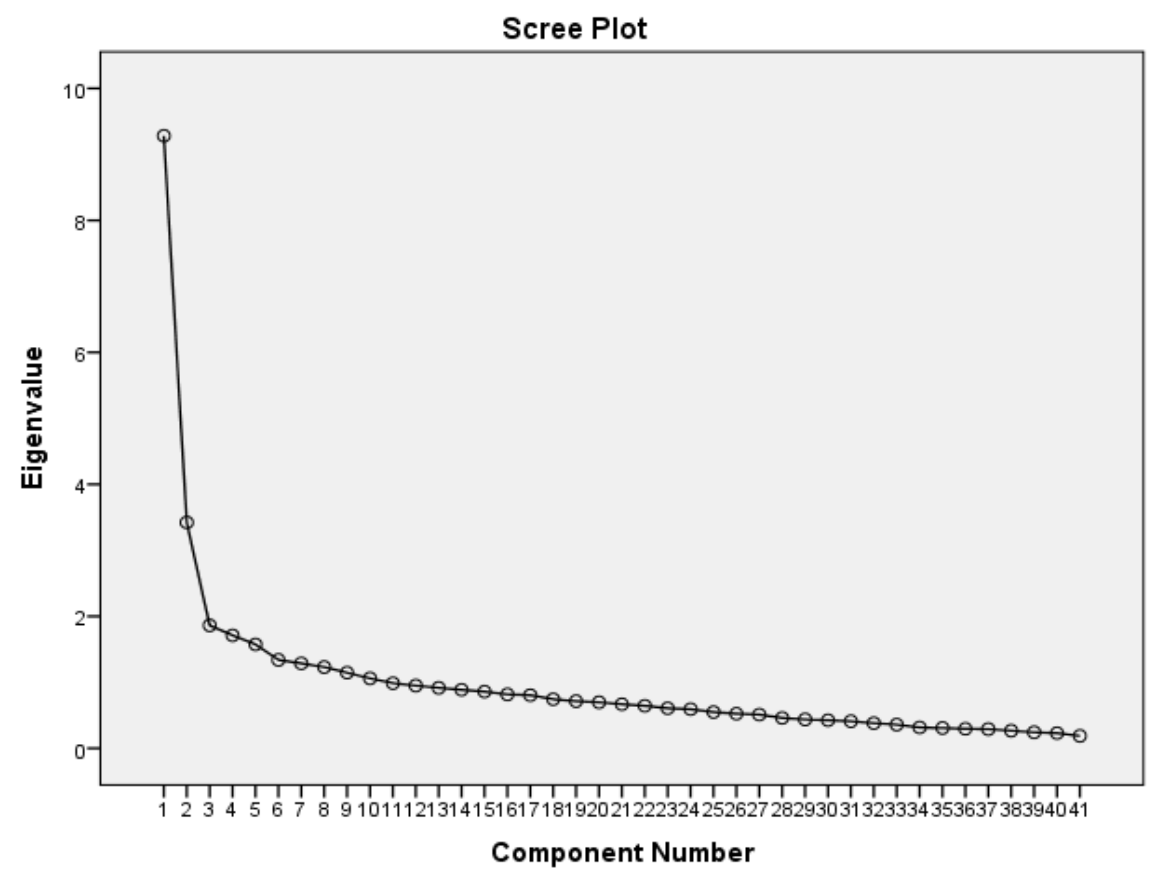

Figure 1: Scree plot of Eigen values of scale component

\section{Concurrent Validity}

The Bangla version of the Rosenberg self-esteem scale was administered on the participants. The Pearson product moment correlation $(r=.311, p<.001)$ is significant which shows that a positive correlation exists between the scores of self-esteem and achievement motivation.

\section{Discussion}

Achievement motivation is an important secondary drive that makes an individual to strive for success and accomplish challenging tasks. Adolescents are the future of the nation. It is important to learn their achievement motivation and 
work accordingly in the education system for a bright future of the country. So, the need of a reliable and valid scale for measuring adolescents' achievement motivation is evident. Hence, the present study was conducted to adapt the DeoMohan Achievement Motivation (n-Ach) Scale in the context of Bangladesh. The adaptation was done following the guidelines of the International Testing Commission (ITC). The test was administered on 228 school students. The item analysis result showed that 9 items of the Bangla version of the scale had a low $(r<.2)$ or negative item-total correlation. Hence, these items were deleted, and the final scale of the Bangla n-Ach scale consisted of 41 items. The high value of Cronbach's alpha and test-retest reliability coefficient established the reliability of the scale.

The content validity was established by the evaluation of the expert panel and the positive correlation between the Bangla n-Ach scale and the Bangla version of Rosenberg self-esteem scale provided the concurrent validity of the scale. The independent sample test indicates that there is no significant variation between male and female in achievement motivation. This finding is supported by a previous research conducted in Bangladesh (Anjuman, 2006)

The values of the KMO and the Bartlett's test indicated that the matrix was significant for factor analysis. The Bangla version of the n-Ach scale had 10 factors that explained $58.33 \%$ of the total variance. Not all the items of the adapted scale conceptually fit with the factors of the original scale. One possible reason could be the different perceptions about the same concept across cultures. The factors of the Bangla n-Ach scale were given new names according to their nature: 'academic motivation', 'need for achievement', 'work methods', 'interest in sports', 'attitude towards competition', 'success seeking', 'attitude towards scholar personalities', 'interest in extra-curricular activities', 'need to excel' and 'relevance of tasks'. The Bangla version of the Achievement Motivation scale had 32 positive items and 9 negative $(1,12,13,16,17,18,19,20,28)$ items. The established reliability and validity proved the adapted Bangla version of the DeoMohan Achievement Scale (n-Ach) as a valid instrument to measure achievement motivation in adolescents.

The Deo-Mohan Achievement Scale (n-Ach) was adapted for urban students in Bangladesh, particularly for those studying in the city of Dhaka. Due to time constraint, it was not possible to expand the study to rural participants. Thus, the obtained data do not allow us to determine rural variance so as to compare with 
urban variance. Hence, a future extensive study can be carried out with a larger sample covering both rural and urban areas that would allow us to make such a comparison. However, it is worth noting that the exclusion of rural participants does not demerit the present study.

\section{References}

Ajayi, B.T. (2002). Relationship between self-esteem and achievement motivation of women in colleges of education. Nigerian Journal of Guidance and Counselling, 8, 221-230. http://dx.doi.org/10.4314/njgc.v8i1.36966

Aktop, K., \& Erman, A. (2006). Relationship between achievement motivation, trait anxiety and self-esteem. Biology of Sport, 2, 3127-141. Retrieved from http://31.186.81.235:8080/api/ files/view/14020.pdf

Anjuman. S. (2006). The impact of sex, family structure and place of residence on achievement motivation. Bangladesh Psychological Studies, 16, 33-46.

Atkinson, J. W. (1957). Motivational determinants of risk-taking behavior. Psychological Review, 64, 359-372. https://doi.org/10.1037/h0043445

Cattell, R.B. (1978). The scientific use of factor analysis. New York: Plenum.

Coopersmith, S. (1967). The antecedents of self-esteem. San Francisco: W. H. Freeman.

Gorsuch, R.L. (1983). Factor analysis (2nd Ed.). Hillsdale, NJ: Erlbaum.

Guilford, J.P. (1956). Psychometric methods. New York: McGraw-Hill.

Deo, P., \& Mohan, A. (1985). Deo-Mohon Achievement Motivation Scale (n-Ach). Agra: National Psychological Corporation.

Entwistle, N. J. (1968). Academic motivation and school attainment. British Journal of Educational Psychology, 38, 181-188. https://doi.org/10.1111/j.2044-8279.1968.tb02003.x

Feldman, R.S. (2017). Understanding psychology (12 ${ }^{\text {th }}$ Ed.), New York, NY: McGraw-Hill.

Ilyas, Q. S. M. (2003). Bangla version of Rosenberg's self-esteem scale. Unpublished manuscript. Department of Psychology, University of Dhaka.

Marascuilo, L. A., \& Levin, J. R. (1983). Multivariate statistics in the social sciences. Monterey, CA: Brooks.

Nunnally, J.C. (1978). Psychometric theory (2nd Ed.). New York: McGraw-Hill.

Kaushik, N., \& Rani, S. (2005). A Comparative study of achievement motivation, home environment and parent child relationship of adolescents. Journal of Psychological Research, 49, 189-194.

Kline, P. (1979). Psychometrics and psychology. London: Academic Press.

McClelland, D. C. (1961). The achieving society. New York: The Free Press.

McClelland, D. C. (1985). How motives, skills, and values determine what people do. American Psychologist, 40, 812-825. https://doi.org/10.1037/0003-066X.40.7.812

McClelland, D. C., Atkinson, J. W., Clark, R. A., \& Lowell, E. L. (1953). Origins of achievement motivation. In D. C. McClelland, J. W. Atkinson, R. A. Clark, \& E. L. Lowell (Eds.) The Achievement Motive: Century Psychology Series (275-318). East Norwalk, CT: AppletonCentury-Crofts. 
Odame-Mensah, S. (2019). Effect of self-esteem on achievement motivation among university students. International Journal of Research and Scientific Innovation (IJRSI), 6, 211-214.

Murray, H.A (1938). Explorations in personality. New York: Oxford University Press.

Nagarathanamma, B., \& Rao, V. T. (2007). Achievement motivation and academic achievement of adolescent boys and girls. Indian Psychological Review, 68, 131-136.

Newcomb, T. M. (1964). Motivation. In J. Gould \& W. L. Kolb (Ed.). A dictionary of the social sciences (447-448). New York: The Free Press.

Rosenberg, M. (1965). Society and the adolescent self-image. Princeton, NJ: Princeton University Press.

Shekhar, C., \& Devi, R. (2012). Achievement motivation across gender and different academic majors. Journal of Educational and Developmental Psychology, 2, 105-109.

Stericker, A. B., \& Johnson, J. E. (1977). Sex-role identification and self-esteem in college students: Do men and women differ? Sex Roles, 3, 19-26.

Tella, A. (2007). The impact of motivation on student's academic achievement and learning outcomes in mathematics among secondary school students in Nigeria. Eurasia Journal of Mathematics, Science and Technology Education, 3, 149-156.

Wani, M. (2015). Achievement motivation: A study with reference to certain demographic variables. The Signage: An International Bi-Annual Bi-Lingual Refereed Journal of Education and Social Sciences, 3, 1-10. 